\title{
STATE OF ART SURVEYS OF OVERVIEWS ON MCDM/MADM METHODS
}

\author{
Edmundas Kazimieras ZAVADSKAS, Zenonas TURSKIS, Simona KILDIENE \\ Department of Construction Technology and Management, Faculty of Civil Engineering, \\ Vilnius Gediminas Technical University, Sauletekio al. 11, 10223 Vilnius, Lithuania
}

Received 31 December 2012; accepted 31 January 2014

\begin{abstract}
Decision-making is primarily a process that involves different actors: people, groups of people, institutions and the state. As a discipline, multi-criteria decision-making has a relatively short history. Since 1950s and 1960s, when foundations of modern multi-criteria decision-making methods have been laid, many researches devoted their time to development of new multi-criteria decision-making models and techniques. In the past decades, researches and development in the field have accelerated and seem to continue growing exponentially. Despite the intensive development worldwide, few attempts have been made to systematically present the theoretical bases and developments of multi-criteria decision-making methods. However, the methodological choices and framework for assessment of decisions are still under discussion. The article describes the situation with reviews of MCDM/MADM methods. Furthermore, there is a need for research to study the strengths and weaknesses of different decision-making methods.
\end{abstract}

Keywords: Multi-Criteria Decision Making (MCDM), Multiple Objective Decision Making (MODM), overview, ISI Web of Science databases.

Reference to this paper should be made as follows: Zavadskas, E. K.; Turskis, Z.; Kildiené, S. 2014. State of art surveys of overviews on MCDM/MADM methods, Technological and Economic Development of Economy 20(1): 165-179.

JEL Classification: C02, C52.

\section{Introduction}

Humans make decisions all the time. Decision-making is a very complex and difficult task. During the past decades, operations research (OR) has come a long way as a field that supports scientific management. OR mainly deals with model building and algorithmic optimization procedures that facilitate the analysis of complex real-world problems (Zopounidis,

Corresponding author Simona Kildienè

E-mail: simona.kildiene@vgtu.lt 
Pardalos 2010). Since von Neumann and Morgenstern (1947) and Savage (1954), this has become the dominant paradigm in decision analysis and decision support in the presence of multiple evaluation dimensions. Traditional OR techniques fit the same purpose: they maximise or minimize a utility function in the presence of constraints. Multi-Criteria Decision Making (MCDM) can be said to be both old and new part of OR, depending on one's frame of reference (Köksalan et al. 2011). MCDM has been one of the fastest growing problem areas in many disciplines. The central problem is how to evaluate a set of alternatives in terms of a number of criteria (Triantaphyllou 2010). Many modern researchers have considered MCDM problems. MCDM refers to making decisions in the presence of multiple, usually conflicting, criteria. The past decades have seen a dramatic increase on all main areas of MCDM:

- Formal models (algorithms, procedures and selection paradigms);

- Evaluation theories (assumptions about values or preferences and structured representations of values or preferences);

- Assessment methodologies (elicitation, estimation and scaling of individuals' preferences, utilities and subjective probabilities in MCDM situations) (Fishburn 1978).

There is no unique and well-defined methodology that one could follow step-by-step from the beginning to the end of a decision aiding process. When dealing with objects that can only be described and compared using several characteristics, aggregation is a major issue: it aims at operating a synthesis of the, usually contradictory, features of the objects, in view of achieving a goal such as choosing among the objects, rank ordering them, sorting them into categories and so on (Bouyssou et al. 2006).

MCDM methods cover a wide range of quite distinct approaches. MCDM methods can be broadly classified into two categories: discrete MCDM or discrete MADM (Multi-attribute Decision Making) and continuous MODM (Multi-Objective Decision Making) methods (Fig. 1). A dictionary definition of a "criterion" is "a means or standard of judging" by which one particular choice or course of action could be judged to be more desirable than another (h). Each problem has multiple, usually conflicting objectives/criteria. Each objective/criterion has a different unit of measurement. MCDM can be perceived as a process of evaluating real-world situations based on various qualitative/quantitative criteria in certain/uncertain/ risky environments in order to find a suitable course of action/choice/strategy/policy among several available options (Raju, Kumar 2013).

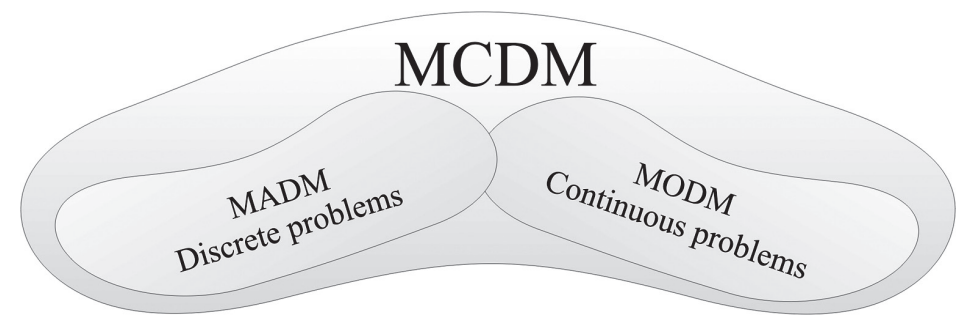

Fig. 1. Broad classification of MCDM methods 
MODM methods are associated with problems where alternatives are non-predetermined and the aim of the problem under consideration is to design the best/optimal alternative by considering a set of well-defined design constraints, a set of quantifiable objectives. Thus, MODM methods deal with the design process and the number of alternatives is infinite (continuous). It is a constant challenge for designers to select the best materials and constructions to satisfy complex design problems (Jahan, Edwards 2013).

MADM art is interrelated with art of the Rational Choice Theory. It assumes that people are motivated by money and by the possibility of making a profit, and this has allowed constructing formal and often predictive models of human behaviour. They act rationally within specific given constraints and based on the information that they have about the conditions under which they are acting. Human actions involve both rational and non-rational elements (Scott 2000). Rational choice theories maintain that individuals must anticipate the outcomes of alternative courses of action and calculate that which will be best for them. As it is not possible for individuals to achieve everything they want, they must also make choices in relation to both their goals and means for attaining these goals. Rational individuals choose the alternative that is likely to give them the greatest satisfaction. Although the expected utility model has many possible founders, Von Neumann and Morgenstern (1947) are usually credited for the first axiomatic foundation of expected utility measurement. Today, the expected utility model is widely used as the normative cornerstone of decision analysis (Keeney, Raiffa 1976).

\section{Main ideas of overview}

Zavadskas and Turskis (2011) published a review of MCDM methods. This study looks at long known and relatively recently published methods. Liou and Tzeng (2012) published an article, which was intended to review the multi-criteria techniques that Zavadskas and Turskis (2011) did not mention in their article. Lately, Liou (2013) summarized the Tzeng's research work. Therefore, this gave rise to an idea to investigate the existing situation with reviews on MCDM/MADM methods.

Discrete MCDM/MADM methods deal with discrete and predetermined alternatives, which are described by a determined discrete criteria set. The main task is:

- Rational selection among limited number of alternatives;

- Assessment and ranking of limited number of alternatives.

Recently, hundreds of publications have been published to provide information about MCDM methods, their development and application in different fields. This article provides an overview of the publication, which provides an overview of MCDM methods. The research is based on Web of Science database, which is a part of Thomson Reuters Web of Knowledge. The 1970s was an important decade for many seminal works. Foundations of modern MCDM were developed in 1950s and 1960s. Development of MCDM researches accelerated during the 80s and early 90s, and seems to have continued its exponential growth (Köksalan et al. 2011). Fig. 2 provides information about this from databases of reference for review of MCDM methods and their application. 
The overview provides systematically classified information on MCDM reviews. They are grouped as shown in Fig. 3:

- Books on MCDM methods (Table 2);

- Articles on multi-criteria methods in scientific journals (Table 3);

- Articles on different MCDM approaches (Table 4);

- Comparative analysis of several MCDM methods (Table 5);

- MCDM review related with individual activity topics (Table 6).

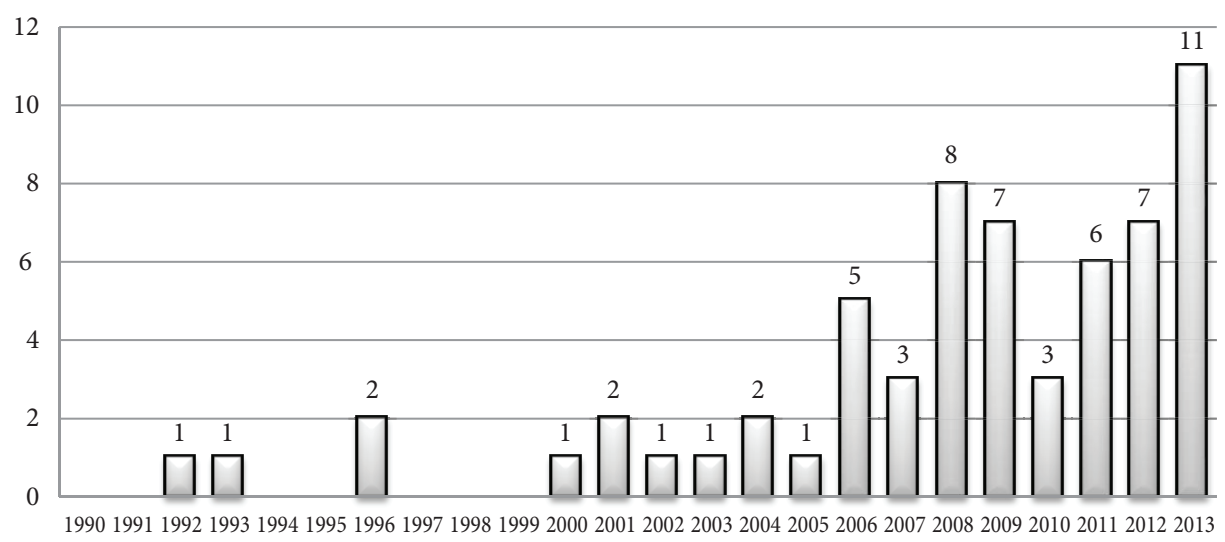

Fig. 2. Number of publications on topic: review papers on MCDM methods (based on ISI Web of Science database)

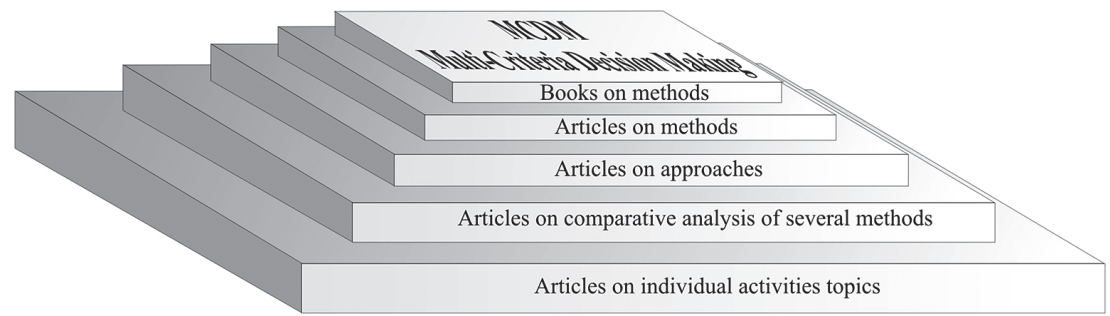

Fig. 3. Five-step pyramid of MCDM reviews

\section{Main results}

Table 1 provides information about the scope of the MCDM methods (Table 1). The total of 71 articles were found on the topic "MCDM review papers" in ISI Web of Science database (December 2013). However, there were only some articles that belonged to few different fields of the research area (Table 1). 
Table. 1. Number of publications by research area MCDM review papers (from database ISI Web of Science)

\begin{tabular}{|c|c|}
\hline MCDM review papers & Number of publications \\
\hline Energy fuels & 18 \\
\hline Operations research management science & 17 \\
\hline Management & 12 \\
\hline Environmental sciences, Ecology & 10 \\
\hline Economics & 5 \\
\hline Environmental sciences & 5 \\
\hline Computer science artificial intelligence & 3 \\
\hline Engineering Electrical Electronic & 3 \\
\hline Biodiversity Conservation & 2 \\
\hline Computer science information systems & 2 \\
\hline Ecology & 2 \\
\hline Environmental studies & 2 \\
\hline Geography & 2 \\
\hline Geography physical & 2 \\
\hline Agronomy & 1 \\
\hline Business & 1 \\
\hline Chemistry Physical & 1 \\
\hline Computer Science interdisciplinary application & 1 \\
\hline Computer Science Software Engineering & 1 \\
\hline Computer Science Theory Methods & 1 \\
\hline Construction Building Technology & 1 \\
\hline Engineering Civil & 1 \\
\hline Engineering Industrial & 1 \\
\hline Engineering Manufacturing & 1 \\
\hline Forestry & 1 \\
\hline Forestry & 1 \\
\hline Health Care Sciences Service & 1 \\
\hline Information Science Library Science & 1 \\
\hline Mathematics Applied & 1 \\
\hline Metallurgy Metallurgical Engineering & 1 \\
\hline Mining Mineral Processing & 1 \\
\hline Obstetrics Gynaecology & 1 \\
\hline Planning Development & 1 \\
\hline Public Environmental Occupational Health & 1 \\
\hline Statistics Probability & 1 \\
\hline Urban Studies & 1 \\
\hline Water Resources & 1 \\
\hline
\end{tabular}

The book by Köksalan et al. (2011) provides a brief history of the development of MCDM methods. It briefly describes the development of the area from ancient to modern times. Keeney and Raiffa (1976) formulated the basics of Decision with Multiple Objectives. Hwang and Masud (1979) provided review on development of MODM methods and applications in a relatively short period of time. Later, Hwang and Yoon (1981) reviewed the MADM methods (SAW, TOPSIS, ELECTRE, LINMAP). 
Saaty (1980) published a detailed study on the analytic hierarchy process (AHP). Later, Saaty (1996) published a study on the further development of the Analytic Network Process (ANP) method. Zeleny (1982) published a book, which deals with the problem of compromise theory. Hwang and Lin (1987) published a study for Group Decision Making under multi-criteria. Roy (1996) summarized the information on ELECTRE group methods. Seminal studies have been prepared by Belton and Stewart (2002), Gal et al. (2009), Miettinen (2009). Brauers (2004) published a study on the basis of which MOORA and MULTIMOORA methods were developed. A great job was done by Figueira et al. (2005), Ehrgott et al. (2010), editing wide studies in which well-known scientists in this area published individual studies on different classes of MCDM methods.

Valuable studies were published by Triantaphyllou (2000, 2010). Hanne (2009) and Kaliszewski (2010) published a detailed study on soft computing intelligent strategies for Meta MCDM. Apparently, this is only a part of all existing noteworthy studies.

Table 2. Books on MCDM methods

\begin{tabular}{|c|c|}
\hline Reference & Considered problem \\
\hline Keeney, Raiffa 1976 & Decision with MODM \\
\hline Hwang, Masud 1979 & MODM methods \\
\hline Saaty 1980 & The analytic hierarchy process \\
\hline Hwang, Yoon 1981 & MADM \\
\hline Zeleny 1982 & MCDM \\
\hline Hwang, Lin 1987 & Group MCDM \\
\hline Zavadskas et al. 1994 & Multi-criteria evaluation of projects in construction \\
\hline Roy 1996 & Multicriteria methodology for decision aiding \\
\hline Saaty 1996 & Decision making with dependence and feedback \\
\hline Peldschus, Zavadskas 1997 & Matrix games in building technology and management \\
\hline Triantaphyllou 2000 & MCDM methods \\
\hline Belton, Stewart 2002 & Multiple criteria decision analysis \\
\hline Figueira et al. (Eds.) 2005 & Multiple criteria decision analysis \\
\hline Bouyssou et al. 2006 & $\begin{array}{l}\text { Evaluation and decision models with multiple criteria: } \\
\text { stepping stones for the analyst }\end{array}$ \\
\hline Chen, Li 2006 & Environmental management in construction \\
\hline Kahraman 2008 & Fuzzy MCDM \\
\hline Gal et al. 2009 & $\begin{array}{l}\text { Multi-criteria decision making advances in MCDM models, } \\
\text { algorithms, theory and applications }\end{array}$ \\
\hline Hanne 2009 & Intelligent strategies for meta MCDM \\
\hline Koo 2009 & Development of sustainability assessment model \\
\hline Miettinen 2009 & Nonlinear multi objective optimization \\
\hline Ballestero, Romero 2010 & MCDM and its applications to economic problems \\
\hline Ehrgott et al. 2010 & Trends in multiple criteria decision analysis \\
\hline Kaliszewski 2010 & Soft computing for complex multiple criteria decision making \\
\hline Pedrycz et al. 2010 & $\begin{array}{l}\text { Decision-making in system project, planning, operation, and } \\
\text { control: motivation, objectives, and basic concepts of fuzzy MCDM }\end{array}$ \\
\hline
\end{tabular}


Continued Table 2

\begin{tabular}{ll}
\hline \multicolumn{1}{c}{ Reference } & \multicolumn{1}{c}{ Considered problem } \\
\hline Triantaphyllou 2010 & MCDM methods: a comparative study \\
\hline Zopounidis, Pardalos 2010 & Multi-criteria analysis \\
\hline Köksalan et al. 2011 & MCDM \\
\hline Tzeng, Huang 2011 & MADM \\
\hline Doumpos, Grigoroudis 2013 & $\begin{array}{l}\text { Recent advances in intelligent decision making and presentation } \\
\text { of hybrid models and algorithms for preference modelling and } \\
\text { optimisation problems }\end{array}$ \\
\hline Ishizaka, Nemery 2013 & Multi-criteria decision analysis \\
\hline Larichev, Olson 2001 & Multiple criteria analysis in strategic siting problems \\
\hline
\end{tabular}

A number of books have been published, which contain detailed information about the MCDM approaches in separate specific areas of research. As an outcome of the development and growing application of MCDM methods, many specific subfields have emerged. Next, some of them are named: Ballestero and Romero (2009) analysed MCDM and its application to economic problems; Peldschus and Zavadskas (1997) analysed an application of discrete matrix games theory in construction and management; Chen and Li (2006) investigated applications of MCDM techniques in environmental management of construction; Zavadskas et al. (1994) applied MCDM in project construction; Venkata (2007) demonstrated how the graph theory and matrix approach as well as fuzzy MADM methods can be effectively used for decision-making in various situations of the manufacturing environment; Koo (2009) presented a study on the development of sustainability assessment model.

Table 3 provides information on reviews of general methods of MCDM. Only some have been listed. A seminal study by Bragge et al. (2012) has been recently published, which was carried out based on bibliometric study of MCDM methods prevalence. A large-scale survey was conducted by Toloie-Eshlaghy and Homayonfar (2011). It gives an overview of about 800 links. Zavadskas and Turskis (2011) provided an overview on MCDM methods based on the traditional classification (Hwang, Yoon 1981).

Table 3. General reviews on MCDM in articles of scientific journals

\begin{tabular}{ll}
\hline \multicolumn{1}{c}{ Reference } & \multicolumn{1}{c}{ Considered problem } \\
\hline Manouselis, Costopoulou 2007 & Analysis and classification of multi-criteria recommender systems \\
\hline El-Wahed 2008 & Intelligent fuzzy MCDM \\
\hline Chu, Lin 2009 & An extension to fuzzy MCDM \\
\hline Zavadskas, Turskis 2011 & Multiple criteria decision making (MCDM) methods in economics \\
\hline Bragge et al. 2012 & $\begin{array}{l}\text { Scholarly communities of research in multiple criteria decision } \\
\text { making: a bibliometric research profiling study }\end{array}$ \\
\hline Liou, Tzeng 2012 & Multiple criteria decision making (MCDM) methods in economics \\
\hline Liou 2013 & New concepts and trends of MCDM \\
\hline Aruldoss et al. 2013 & $\begin{array}{l}\text { A survey on multi criteria decision making methods } \\
\text { and its applications }\end{array}$ \\
\hline
\end{tabular}


A number of publications can be found in regional journals, such as Alias et al. (2008), and several publications, which provide an overview on the theory of fuzzy MCDM applications, such as Chu, Lin (2009), El-Wahed (2008) and the analysis and classification of multi-criteria systems.

Significantly more review articles on separate MCDM methods (Table 4) have been published. Kaplinski and Tamošaitienè (2010) reviewed applications of discrete matrix game theory, Behzadian et al. (2010) - PROMETHEE method, and Behzadian et al. (2012) TOPSIS method. Zopounidis and Doumpos (2002) conducted a review on a multi-criteria classification and sorting. Adler et al. (2002) reviewed the DEA method's applications. Shih (2008) conducted a review on TOPSIS group methods. Ishizaka, Labib (2011) and Ho (2008) publications were devoted to the analysis of AHP method. Jadhav and Rajendra Sonar (2009) overviewed MCDM software packages. Baležentis and Baležentis (2013) published a review article on MULTIMOORA method.

Table 4. Overview on application of different MCDM methods

\begin{tabular}{ll}
\hline \multicolumn{1}{c}{ Reference } & \multicolumn{1}{c}{ Considered problem } \\
\hline Adler et al. 2002 & Data Envelopment Analysis (DEA) \\
\hline Zopounidis, Doumpos 2002 & Multicriteria classification and sorting methods \\
\hline Ho 2008 & Integrated analytic hierarchy process \\
\hline Shih 2008 & MCDM with an application to group TOPSIS \\
\hline Jadhav, Rajendra Sonar 2009 & Software packages \\
\hline Cook, Seiford 2009 & Data envelopment analysis (DEA) \\
\hline Kapliński, Tamosaitiene 2010 & Game theory application \\
\hline Behzadian et al. 2010 & PROMETHEE \\
\hline Ishizaka, Labib 2011 & Analytic hierarchy process \\
\hline Behzadian et al. 2012 & A state-of the-art survey of TOPSIS applications \\
\hline Balezentis, T., & Applications of the multi criteria decision making method \\
Balezentis, A. 2013 & MULTIMOORA \\
\hline
\end{tabular}

A significantly greater number of publications have been devoted to comparative analysis of separate MCDM methods (Table 5). Opricovic and Tzeng (2004) conducted a benchmarking on TOPSIS and VIKOR methods. Simanavičienè and Ustinovičius (2012) provided a benchmarking on TOPSIS, SAW and COPRAS methods. Podvezko (2011) conducted a comparative study of SAW and COPRAS methods and Podviezko (2012) provided a comparative study on SAW, PROMETHEE, TOPSIS, and COPRAS methods. Albiñana and Vila (2012) conducted benchmarking on VIKOR, ELECTRE, COPRAS, and EVAMIX methods. A benchmarking MOORA, AHP, TOPSIS, VIKOR, ELECTRE and PROMETHEE methods has been provided by Chakraborty (2011). Interesting and valuable work in the field of MCDM benchmarking has been performed by Kou et al. (2012), Peng et al. (2011), Baležentis et al. (2012) and Stanujkic et al. (2012). Antuchevičienè et al. (2011, 2012) carried out investigation on fuzzy MCDM methods (TOPSIS, VIKOR and COPRAS) and provided a comparative analysis. A large number of valuable works has been conducted, which enables us to evaluate the positive and negative characteristics of different MCDM methods and their ability to help solving real practical problems in different areas. 
Table 5. Comparative analysis of MCDM methods

\begin{tabular}{ll}
\hline \multicolumn{1}{c}{ Reference } & \multicolumn{1}{c}{ Considered problem } \\
\hline Kou et al. 2012 & $\begin{array}{l}\text { Evaluation of classification algorithms using MCDM } \\
\text { and rank correlation }\end{array}$ \\
\hline Peng et al. 2011 & FAMCDM \\
\hline Podvezko 2011 & Comparative analysis SAW and COPRAS \\
\hline Antuchevičiene et al. 2012 & Comparative analysis of FTOPSIS, FVIKOR and COPRAS-F \\
\hline Antuchevičienè et al. 2011 & $\begin{array}{l}\text { Measuring congruence of ranking results applying particular } \\
\text { MCDM methods }\end{array}$ \\
\hline Opricovic, Tzeng 2004 & TOPSIS and VIKOR \\
\hline Simanavičiené, Ustinovičius 2012 & TOPSIS, SAW, COPRAS \\
\hline Chakraborty 2011 & MOORA, AHP, TOPSIS, VIKOR, ELECTRE, PROMETHEE \\
\hline Baležentis et al. 2012 & VIKOR, TOPSIS, ARAS \\
\hline Albiñana, Vila 2012 & VIKOR, ELECTRE, COPRAS, EVAMIX \\
\hline Stanujkic et al. 2012 & Comparative analysis of some prominent MCDM methods \\
\hline
\end{tabular}

Table 6. MCDM review on topics of individual activities

\begin{tabular}{ll}
\hline \multicolumn{1}{c}{ Reference } & \multicolumn{1}{c}{ Considered problem } \\
\hline Greening, Bernow 2004 & Design of coordinated energy and environmental policies \\
\hline Melo et al. 2009 & Facility location and supply chain management \\
\hline Moffett, Sarkar 2006 & Design of conservation area networks \\
\hline Ananda, Herath 2009 & Forest management and planning \\
\hline Diaz-Balteiro, Romero 2008 & Forestry decisions \\
\hline Ehrgott et al. 2004 & Portfolio optimization \\
\hline Ho et al. 2010 & Supplier evaluation and selection \\
\hline Jahan et al. 2010 & Material screening and choosing \\
\hline Xidonas, Psarras 2009 & Equity portfolio management \\
\hline Kaplinski, Tupenaite 2011 & Modern construction economics \\
\hline Wang et al. 2009 & Sustainable energy \\
\hline Kapliński, Peldschus 2011 & Social science \\
\hline Huang et al. 2011 & Environmental sciences \\
\hline Zavadskas et al. 2008 & Quality in bridges and road construction \\
\hline Yazdani-Chamzini et al. 2013 & Selecting the optimal renewable energy \\
\hline Tamošaitiené, Kaplinski 2013 & Application of MCDM methods in social sciences \\
\hline Kabir et al. 2013 & $\begin{array}{l}\text { A review of multi-criteria decision-making methods for } \\
\text { infrastructure management }\end{array}$ \\
\hline
\end{tabular}

Reviews on topics of individual activities can be identified into a separate group of reviews on MCDM methods. Ehrgott et al. (2004), Xidonas and Psarras (2009) applied the MCDM methods to portfolio optimization and management; Jahan et al. (2010) - material choosing and screening; Diaz-Balteiro and Romero (2008) - forestry-related decisions; Ananda and Herath (2009) - forest management and planning. Greening and Bernow (2004) applied the MCDM methods to design of Coordinated Energy and Environmental Policy; Moffett 
and Sarkar (2006) - design of conservation area networks. Kaplinski and Tupènaitè (2011) reviewed the latest MCDM applications in modern construction economics. Wang et al. (2009) and Yazdani-Chamzini et al. (2013) reviewed MCDM applications for energy systems assessment. Kaplinski and Peldschus (2011) and Tamošaitienè and Kaplinski (2013) reviewed the applications of MCDM methods in the social sciences; Zavadskas et al. (2008) reviewed the applications of MCDM methods in the area of bridge and road construction; and Huang et al. (2011) - MCDM methods in the social sciences.

\section{Conclusions}

The paper presents synopsis of numerous publications, which describe the use of traditional MCDM methods and some of the relatively recently developed methods. However, this review does not cover recent methods that have not yet been reviewed in articles or books. However, it is worth noting that publications reviewed in this article at least allow for a partial representation of the structure of those MCDM methods, which are gaining wider use.

Recently, development of hybrid and modular methods is becoming increasingly important. They are based on previously developed well-known methods, such as TOPSIS, SAW, DEA, AHP, ANP, VIKOR, DEMATEL, DEA, PROMETHEE, ELECTRE and their modification, by applying fuzzy and grey number theory. Relatively recently developed MCDM methods, such as COPRAS, ARAS, MOORA, MULTIMOORA, SWARA and WASPAS are rapidly developed and applied to solve real life problems. In order to help researchers and practitioners interested in hybrid MCDM techniques and applications of hybrid MCDM methods, it is necessary to publish reviews on these issues in future.

\section{References}

Adler, N.; Friedman, L.; Sinuany-Stern, Z. 2002. Review of ranking methods in the data envelopment analysis context, The European Journal of Operational Research 140(2): 249-265. http://dx.doi.org/10.1016/S0377-2217(02)00068-1

Albiñana, J. C.; Vila, C. 2012. A framework for concurrent material and process selection during conceptual product design stages, Materials and Design 41(10): 433-446.

http://dx.doi.org/10.1016/j.matdes.2012.05.016

Alias, M. A.; Hashim, S. Z. M.; Samsudin, S. 2008. Multi-criteria decision making and it applications: literature review, Jurnal Teknologi Maklumat 20(2): 129-152.

Ananda, J.; Herath, G. 2009. A critical review of multi-criteria decision making methods with special reference to forest management and planning, Ecological Economics 68(10): 2535-2548. http://dx.doi.org/10.1016/j.ecolecon.2009.05.010

Antuchevičienė, J.; Zakarevičius, A.; Zavadskas, E. K. 2011. Measuring congruence of ranking results applying particular MCDM methods, Informatica 22(3): 319-338.

Antuchevičienė, J.; Zavadskas, E. K.; Zakarevičius, A. 2012. Ranking redevelopment decisions of derelict buildings and analysis of ranking results, Economic Computation and Economic Cybernetics Studies and Research 46(2): 37-62.

Aruldoss, M.; Lakshmi, T. M.; Venkatesan, V. P. 2013. a survey on multi criteria decision making methods and its applications, American Journal of Information Systems 1(1): 31-43. 
Baležentis, A.; Baležentis, T.; Misiunas, A. 2012. An integrated assessment of Lithuanian economic sectors based on financial ratios and fuzzy MCDM methods, Technological and Economic Development of Economy 18(1): 34-53. http://dx.doi.org/10.3846/20294913.2012.656151

Balezentis, T.; Balezentis, A. 2013. A survey on development and applications of the multi criteria decision-making method MULTIMOORA, Journal of Multi-Criteria Decision Analysis (in Press).

Ballestero, E.; Romero, C. 2010. Multiple criteria decision making and its applications to economic problems. Berlin: Springer. $168 \mathrm{p}$.

Behzadian, M.; Kazemzadeh, R. B.; Albadvi, A.; Aghdasi, M. 2010. PROMETHEE: a comprehensive literature review on methodologies and applications, European Journal of Operational Research 200(1): 198-215. http://dx.doi.org/10.1016/j.ejor.2009.01.021

Behzadian, M.; Otaghsara, S. K.; Yazdani, M.; Ignatius, J. 2012. A state-of the-art survey of TOPSIS applications, Expert Systems with Applications 39(17): 13051-13069.

http://dx.doi.org/10.1016/j.eswa.2012.05.056

Belton, V.; Stewart, T. J. 2002. Multiple criteria decision analysis: an integrated approach. Dordrecht: Kluwer Academic Publishers. 372 p. http://dx.doi.org/10.1007/978-1-4615-1495-4

Bouyssou, D.; Marchant, T.; Pirlot, M.; Tsoukias, A.; Vincke, P. 2006. Evaluation and decision models with multiple criteria: stepping stones for the analyst. New York: Springer. 459 p.

Bragge, J.; Korhonen, P.; Wallenius, H.; Wallenius, J. 2012. Scholarly communities of research in multiple criteria decision making: a bibliometric research profiling study, International Journal of Information Technology \& Decision Making 11(2): 401-426. http://dx.doi.org/10.1142/S0219622012400081

Brauers, W. K. 2004. Optimization methods for a stakeholder society, a revolution in economic thinking by multi-objective optimization, series: nonconvex optimization and its applications. Vol. 73. Boston-Dordrecht-London: Kluwer Academic Publishers and Springer. 342 p. http://dx.doi.org/10.1007/978-1-4419-9178-2

Chakraborty, S. 2011. Applications of the MOORA method for decision making in manufacturing environment, The International Journal of Advanced Manufacturing Technology 54(9-12): 1155-1166. http://dx.doi.org/10.1007/s00170-010-2972-0

Chen, Z.; Li, H. 2006. Environmental management in construction. A quantitative approach. London and New York: Taylor \& Francis. 232 p.

Chu, T.-C.; Lin, Y. 2009. An extension to fuzzy MCDM, Computers \& Mathematics with Applications 57(3): 445-454. http://dx.doi.org/10.1016/j.camwa.2008.10.076

Cook, W. D.; Seiford, L. M. 2009. Data envelopment analysis (DEA) - thirty years on, European Journal of Operational Research 192(1): 1-17. http://dx.doi.org/10.1016/j.ejor.2008.01.032

Diaz-Balteiro, L.; Romero, C. 2008. Making forestry decisions with multiple criteria: a review and an assessment, Forest Ecology and Management 255(8-9): 3222-3241. http://dx.doi.org/10.1016/j.foreco.2008.01.038

Doumpos, M.; Grigoroudis, E. 2013. Multicriteria decision aid and artificial intelligence: links, theory and applications. Chichester: Wiley-Blackwell. 368 p.

Ehrgott, M.; Figueira, R. J.; Greco, S. 2010. Trends in multiple criteria decision analysis. New York, Dordrecht, Heidelberg, London: Springer. 412 p. http://dx.doi.org/10.1007/978-1-4419-5904-1

Ehrgott, M.; Klamroth, K.; Schwehmc, C. 2004. An MCDM approach to portfolio optimization, European Journal of Operational Research 155(3): 752-770. http://dx.doi.org/10.1016/S0377-2217(02)00881-0

El-Wahed, W. F. A. 2008. Intelligent fuzzy multi-criteria decision making: review and analysis, Fuzzy Multi-Criteria Decision Making Springer Optimization and its Applications 16: 19-50.

Figueira, J.; Greco, S.; Ehrgott, M. (Eds.). 2005. Multiple criteria decision analysis: state of the art survey. Boston: Springer. $1048 \mathrm{p}$. 
Fishburn, P. C. 1978. A survey of multiattibute/multicriterion evaluation theories, in S. Zionts (Ed.). Multicriteria problem solving. Berlin: Springer Verlag, 181-224.

Gal, T.; Stewart, T. J.; Hanne, T. 2009. Multicriteria decision making advances in MCDM models, algorithms, theory and applications. Berlin: Springer. $564 \mathrm{p}$.

Greening, L. A.; Bernow, S. 2004. Design of coordinated energy and environmental policies: use of multi-criteria decision-making, Energy Policy 32(6): 721-735. http://dx.doi.org/10.1016/j.enpol.2003.08.017

Hanne, T. 2009. Intelligent strategies for meta multiple criteria decision making. Berlin: Springer. $216 \mathrm{p}$.

Ho, W. 2008. Integrated analytic hierarchy process and its applications - a literature review, European Journal of Operational Research 186(1): 211-228. http://dx.doi.org/10.1016/j.ejor.2007.01.004

Ho, W.; Xu, X.; Dey, P. K. 2010. Multi-criteria decision making approaches for supplier evaluation and selection: a literature review, European Journal of Operational Research 202(1): 16-24. http://dx.doi.org/10.1016/j.ejor.2009.05.009

Huang, I. B.; Keisler, J.; Linkov, I. 2011. Multi-criteria decision analysis in environmental sciences: ten years of applications and trends, Science of the Total Environment 409(19): 3578-3594. http://dx.doi.org/10.1016/j.scitotenv.2011.06.022

Hwang, C. L.; Masud, A. S. M. 1979. Multiple objective decision making methods and applications, a state of the art survey, Lecture Notes in Economics and Mathematical Systems. Vol. 164. Berlin: Springer-Verlag. 357 p. http://dx.doi.org/10.1007/978-3-642-45511-7

Hwang, C. L.; Yoon, K. 1981. Multiple attributes decision making methods and applications. Berlin, Heidelberg: Springer. 269 p. http://dx.doi.org/10.1007/978-3-642-48318-9

Hwang, C. L.; Lin, M. J. 1987. Group decision making under multiple criteria: methods and applications. Berlin: Springer-Verlag. 405 p. http://dx.doi.org/10.1007/978-3-642-61580-1

Ishizaka, A.; Labib, A. 2011. Review of the main developments in the analytic hierarchy process, Expert Systems with Applications 38(11): 14336-14345.

Ishizaka, A.; Nemery, P. 2013. Multi-criteria decision analysis: methods and software. Chichester: John Wiley \& Sons. 296 p.

Jadhav, A. S.; Rajendra Sonar, R. M. 2009. Evaluating and selecting software packages: a review, Information and Software Technology 51(3): 555-563. http://dx.doi.org/10.1016/j.infsof.2008.09.003

Jahan, A.; Ismail, M. Y.; Sapuan, S. M.; Mustaph, F. 2010. Material screening and choosing methods - a review, Materials \& Design 31(2): 696-705. http://dx.doi.org/10.1016/j.matdes.2009.08.013

Jahan, A.; Edwards, K. L. 2013. VIKOR method for material selection problems with interval numbers and target-based criteria, Materials \& Design 47: 759-765.

Kabir, G.; Sadiq, R.; Tesfamariam, S. 2013. A review of multi-criteria decision-making methods for infrastructure management, Structure and Infrastructure Engineering: Maintenance, Management, Life-Cycle Design and Performance. London: Taylor and Francis. 36 p. http://dx.doi.org/10.1080/15732479.2013.795978

Kahraman, C. 2008. Fuzzy multi-criteria decision making. Theory and applications with recent developments. Turkey: Springer, Science+Business Media, LLC. 591 p.

Kaliszewski, I. 2010. Soft computing for complex multiple criteria decision making. Berlin: Springer. $172 \mathrm{p}$.

Kapliński, O.; Peldschus, F. 2011. The problems of quantitative evaluation of socio-economic systems' development: review, Inzinerine Ekonomika - Engineering Economics 22(4): 345-355.

Kapliński, O.; Tamošaitienè, J. 2010. Game theory applications in construction engineering and management, Technological and Economic Development of Economy 16(2): 348-363. http://dx.doi.org/10.3846/tede.2010.22

Kaplinski, O.; Tupenaite, L. 2011. Review of the multiple criteria decision making methods, intelligent and biometric systems applied in modern construction economics, Transformations in Business \& Economics 10(1): 166-181. 
Keeney, R. L.; Raiffa, H. 1976. Decision with multiple objectives: preferences and value trade-offs. New York: John Wiley \& Sons. 569 p.

Köksalan, M. M.; Wallenius, J.; Zionts, S. 2011. Multiple criteria decision making: from early history to the 21st century. Singapore; Hackensack, NJ: World Scientific. 200 p.

Koo, D. H. 2009. Development of sustainability assessment model. Development of sustainability assessment model for underground infrastructure. VDM Verlag Dr. Müller. $184 \mathrm{p}$.

Kou, G.; Lu, Y.; Peng, Y.; Shi, Y. 2012. Evaluation of classification algorithms using MCDM and rank correlation, International Journal of Information Technology \& Decision Making 11(1): 197-225. http://dx.doi.org/10.1142/S0219622012500095

Larichev, O. I.; Olson, D. L. 2001. Multiple criteria analysis in strategic siting problems. Norwell: Kluwer Academic Publishers. 217 p.

Liou, J. J. H. 2013. New concepts and trends of MCDM for tomorrow - in honor of Professor Gwo-Hshiung Tzeng on the occasion of his 70th birthday, Technological and Economic Development of Economy 19(2): 367-375. http://dx.doi.org/10.3846/20294913.2013.811037

Liou, J. J. H.; Tzeng, G.-H. 2012. Comments on "Multiple criteria decision making (MCDM) methods in economics: an overview", Technological and Economic Development of Economy 18(4): 672-695. http://dx.doi.org/10.3846/20294913.2012.753489

Manouselis, N.; Costopoulou, C. 2007. Analysis and classification of multi-criteria recommender systems, World Wide Web 10(4): 415-441. http://dx.doi.org/10.1007/s11280-007-0019-8

Melo, M. T.; Nickel, S.; Saldanha-da-Gama, F. 2009. Facility location and supply chain management - a review, European Journal of Operational Research 169(2): 401-412. http://dx.doi.org/10.1016/j.ejor.2008.05.007

Miettinen, K. 2009. Nonlinear multiobjective optimization. Berlin: Springer. 320 p.

Moffett, A.; Sarkar, S. 2006. Incorporating multiple criteria into the design of conservation area networks: a minireview with recommendations, Diversity and Distributions 12(2): 125-137. http://dx.doi.org/10.1111/j.1366-9516.2005.00202.x

Opricovic, S.; Tzeng, G. H. 2004.Compromise solution by MCDM methods: a comparative analysis of VIKOR and TOPSIS, European Journal of Operation Research 156(2): 445-455. http://dx.doi.org/10.1016/S0377-2217(03)00020-1

Pedrycz, W.; Ekel, P.; Parreiras, R. 2010. Fuzzy multicriteria decision-making: models, methods and applications. Chichester: John Wiley \& Sons Ltd. 360 p. http://dx.doi.org/10.1002/9780470974032

Peldschus, F.; Zavadskas, E. 1997. Matrix games in building technology and management. Vilnius: Technika. 134 p. (in Lithuanian).

Peng, Y.; Kou, G.; Wang, G.; Shi, Y. 2011. FAMCDM: a fusion approach of MCDM methods to rank multiclass classification algorithms, Omega 39(6): 677-689. http://dx.doi.org/10.1016/j.omega.2011.01.009

Podviezko, A. 2012. Augmenting multicriteria decision aid methods by graphical and analytical reporting tools, Lecture in Business Information Processing 106: 236-251. http://dx.doi.org/10.1007/978-3-642-29231-6_19

Podvezko, V. 2011. The comparative analysis of MCDA methods SAW and COPRAS, Inzinerine Ekonomika - Engineering Economics 2(22): 134-146.

Raju, K. S.; Kumar, D. M. 2013. Multicriterion analysis in engineering and management. Kindle edition. PHI Learning Private Limited. 343 p.

Roy, B. 1996. Multicriteria methodology for decision aiding. Dortrecht: Kluwer Academic Publishers. 293 p. http://dx.doi.org/10.1007/978-1-4757-2500-1

Saaty, T. L. 1980. The analytic hierarchy process. New York: McGraw-Hill. 287 p.

Saaty, T. L. 1996. Decision making with dependence and feedback: the analytic network process. Pittsburgh: RWS Publications. 370 p. 
Scott, J. 2000. Rational choice theory, in Browning, G. (Ed.). From understanding contemporary society: theories of the present. London: SAGE Publications Ltd, 126-139. http://dx.doi.org/10.4135/9781446218310.n9

Savage, L. J. 1954. The foundations of statistics. Second revised edition. New York: Wiley. 112 p.

Shih, H.-S. 2008. Incremental analysis for MCDM with an application to group TOPSIS, European Journal of Operational Research 186(2): 720-734. http://dx.doi.org/10.1016/j.ejor.2007.02.012

Simanavičienė, R.; Ustinovičius, L. 2012. A new approach to assessing the biases of decisions based on multiple attribute decision making methods, Elektronics and Electrical Engineering - Elektronika ir Elektrotechnika 1(117): 29-32.

Stanujkic, D.; Magdalinovic, N.; Jovanovic, R.; Stojanovic, S. 2012. An objective multi-criteria approach to optimization using MOORA method and interval grey numbers, Technological and Economic Development of Economy 18(2): 331-363. http://dx.doi.org/10.3846/20294913.2012.676996

Tamošaitienè, J.; Kaplinski, O. 2013. Strategic Environmental Assessment (SEA) of socio-economic systems: a systematic review, Technological and Economic Development of Economy 19(4): 661-674. http://dx.doi.org/10.3846/20294913.2013.862882

Toloie-Eshlaghy, A.; Homayonfar, M. 2011. MCDM methodologies and applications: a literature review from 1999 to 2009, Research Journal of International Studies (21): 86-137.

Triantaphyllou, E. 2000. Multi-criteria decision making methods: a comparative study. Dordrecht: Kluwer Academic Publishers. 289 p. http://dx.doi.org/10.1007/978-1-4757-3157-6

Triantaphyllou, E. 2010. Multi-criteria decision making methods: a comparative study. Dordrecht: Springer. $288 \mathrm{p}$.

Tzeng, G.-H.; Huang, J.-J. 2011. Multiple attribute decision making. New York: CRC Press. 349 p.

Venkata, R. R. 2007. Decision making in the manufacturing environment: using graph theory and fuzzy multiple attribute decision making methods. London, Heidelberg, New York, Dordrecht: Springer. 391 p.

Von Neumann, J.; Morgenstern, O. 1947. Theory of games and economic behavior. 2nd ed. Princeton: Princeton University Press. 641 p.

Wang, J.-J.; Jing, Y.-Y.; Zhang, C.-F.; Zhao, J.-H. 2009. Review on multi-criteria decision analysis aid in sustainable energy decision-making, Renewable and Sustainable Energy Reviews 13(9): 2263-2278. http://dx.doi.org/10.1016/j.rser.2009.06.021

Xidonas, P.; Psarras, J. 2009. Equity portfolio management within the MCDM frame: a literature review, International Journal of Banking, Accounting and Finance 1(3): 285-309.

Yazdani-Chamzini, A.; Fouladgar, M. M.; Zavadskas, E. K.; Moini, S. H. H. 2013. Selecting the optimal renewable energy using multi criteria decision making, Journal of Business Economics and Management 14(5): 957-978. http://dx.doi.org/10.3846/16111699.2013.766257

Zavadskas, E. K.; Liias, R.; Turskis, Z. 2008. Multi-attribute decision-making methods for assessment of quality in bridges and road construction: state-of-the-art surveys, The Baltic Journal of Road and Bridge Engineering 3(3): 152-160. http://dx.doi.org/10.3846/1822-427X.2008.3.152-160

Zavadskas, E.; Peldschus, F.; Kaklauskas, A. 1994. Multiple criteria evaluation of projects in construction. Vilnius: Technika. $226 \mathrm{p}$.

Zavadskas, E. K.; Turskis, Z. 2011. Multiple criteria decision making (MCDM) methods in economics: an overview, Technological and Economic Development of Economy 17(2): 397-427. http://dx.doi.org/10.3846/20294913.2011.593291

Zeleny, M. 1982. Multiple criteria decision making. New York: McGraw-Hill. 563 p.

Zopounidis, C.; Doumpos, M. 2002. Multicriteria classification and sorting methods: a literature review, European Journal of Operational Research 138(2): 229-246.

http://dx.doi.org/10.1016/S0377-2217(01)00243-0

Zopounidis, C.; Pardalos, P. M. (Eds.). 2010. Handbook of multicriteria analysis. Berlin, Heidelberg: Springer-Verlag. 455 p. http://dx.doi.org/10.1007/978-3-540-92828-7 
Edmundas Kazimieras ZAVADSKAS. PhD, DSc, h.c.multi. Prof., the Head of the Department of Construction Technology and Management of Vilnius Gediminas Technical University, Lithuania. Senior Research Fellow at the Research Institute of Smart Building Technologies. PhD in Building Structures (1973). Dr Sc. (1987) in Building Technology and Management. A member of Lithuanian and several foreign Academies of Sciences. Doctore Honoris Causa from Poznan, Saint Petersburg and Kiev universities. The Honorary International Chair Professor in the National Taipei University of Technology. A member of international organizations; a member of steering and programme committees at many international conferences; a member of the editorial boards of several research journals; the author and co-author of more than 400 papers and a number of monographs in Lithuanian, English, German and Russian. Editor-in-chief of journals Technological and Economic Development of Economy and Journal of Civil Engineering and Management. Research interests: building technology and management, decision-making theory, automation in design and decision support systems.

Zenonas TURSKIS. PhD from VISI (Vilnius Engineering Construction Institute, former name of Vilnius Gediminas Technical University). He works at the Construction Department of Vilnius Gediminas Technical University. He has more than 100 publications in journals such as International Journal of Information Technology \& Decision Making, Economic Research, Journal of Economic Computation and Economic Cybernetics Studies and Research (ECECSR) and more. His research interests include automated programming, technological decision multicriteria evaluation in construction and investment areas.

Simona KILDIENĖ. PhD student at the Department of Construction Technology and Management of Vilnius Gediminas Technical University, Vilnius, Lithuania. Master of Science (construction engineering), VGTU, 2010. Bachelor of Science (construction management), VGTU, 2008. Research interests include construction economics, construction management, multiple criteria analysis and decision-making theories. 